\title{
A Conceptual Model of Children's Rights and Community-Based Values to Promote Social Justice Through Early Childhood Curriculum Frameworks
}

\author{
Rachel Caplan, Colleen Loomis, and Aurelia Di Santo
}

Rachel Caplan is a doctoral student in the Department of Psychology, Wilfrid Laurier University, with research interests that include early childhood education and social policy, child and family health and well-being, and child and family homelessness. Email: cap10410@mylaurier.ca

Colleen Loomis is an associate professor in the Department of Psychology, Wilfrid Laurier University, with expertise in early childhood studies. Her local, national, and international research focuses on linking community, schools, government, and nongovernmental organizations to foster children's development to its full capacity, preventing developmental issues.

Aurelia Di Santo is an associate professor in the School of Early Childhood Studies, Ryerson University. Her research includes children's rights, children's participation in research and in their early learning programs, transitions to school, and play-based learning.

A "rights-integrative approach to early learning" has been proposed as a foundation for curriculum frameworks. Building on this work we conceptually explored the complementarity and compatibility of children's rights to autonomy, protection, nondiscrimination, and participation, with community-based values of prevention and promotion, empowerment, diversity, and civic participation. We argue that it is necessary to infuse a rights-based approach with community-based values in early childhood curriculum frameworks to promote social justice for children as individuals and as a relational community. Our proposed expanded conceptual framework may be useful for evaluating early learning frameworks, nationally and internationally, from a rights-based social justice perspective.

Keywords: early childhood curriculum, children's rights, community values, social justice

which will contribute to the shift called for by Di Santo and Kenneally (2014) toward the realization of children's citizenship and agency rights and responsibilities within society.

\section{Background}

\section{Early Childhood Education and Children's Rights}

Early childhood is one of the most critical periods in a person's life (Gallahue \& Ozmun, 2011). Neuroplasticity occurring at significant rates during early childhood creates opportune periods for cognitive, social, physical, spiritual, and emotional growth:

Early childhood education is important in its own right as a time when children inquire, explore and discover a great deal about the world around them and establish attitudes to learning that remain with them throughout their lives. (Victorian Curriculum and Assessment 
Authority, 2008, p. 6)

Governments in many countries have ECE policies, and some have advanced an explicit mandate or framework that guides funding, teacher training, and curriculum. While Canadian advocates continue working toward universal, accessible, high-quality early childhood education and care (ECEC) programs across Canada (Friendly \& Prentice, 2009), early childhood learning frameworks have been designed in various provinces and utilized as pedagogical guides or tools within ECEC environments (Langford, 2012). These curriculum frameworks provide opportunities to accelerate awareness and realization of children's rights and values associated with social justice. For example, the British Columbia Early Learning Framework includes a subsection devoted specifically to explaining "The United Nations Rights of the Child" (Government of British Columbia, 2008, p. 7). However, the degree and efficacy to which children's rights have been incorporated into the framework can only be assessed through a comprehensive document analysis.

To protect children's rights, Canada ratified the United Nations Convention on the Rights of the Child (UNCRC) in 1991, declaring children as citizens, rather than property (United Nations, 1989). In addition to provisional rights to competent standards of care, compulsory and free primary education, play, rest and leisure, etc., children have rights to protection from violence, abuse, neglect, discrimination, etc., and rights to participation through freely expressing their views, thoughts, religion, etc. (Penn, 2008). Integrated within these three domains of rights (i.e., provision, protection, and participation) are the four guiding principles of the UNCRC, namely children's rights to nondiscrimination (Article 2); the best interest of the child (Article 3); life, survival, and development (Article 6); and respect for the views of the child (Article 12; United Nations, 1989). Using the four guiding principles as a framework to analyze Ontario's Early Learning for Every Child Today (ELECT; Government of Ontario, 2007) document, Di Santo and Kenneally (2014) proposed a practical approach to assist educators in using what they termed a "rights-integrative approach to early learning" (p. 396). For example, with respect to children's rights to nondiscrimination (Article 2), they suggested that educators look for "how children's rights are recognized" and "how diversity, equity, and inclusion are made explicit" (p. 405) in their curriculum documents. To support the best interest of the child (Article 3), they suggested that educators ask themselves, "How do I share power and consider children's individual capacity in my practice?" (p. 405). With respect to children's rights to life, survival, and development (Article 6), educators can look for "opportunities where children direct their own development - have the freedom to explore and play on their own terms - with, where, and as long as they choose" (p. 405). To respect the views of each child (Article 12), they suggested that educators ask themselves: "What are the opportunities built into our day-to-day program that support children in practicing problem-solving and decision-making among themselves?" and "How do I listen seriously to what children are saying and feeling?" (p. 405).

\section{Social Justice}

Definitions, types, and conceptualizations of social justice have been long disputed and vary across and within disciplines (Evans, Rosen, \& Nelson, 2014; Kruger, 2004; Munger, MacLeod, \& Loomis, 2016; Riemer \& Van Voorhees, 2014; Sloan, 2010). For the purpose of this paper, social justice refers to individual and collective well-being, whereby the rights of all living beings and the ecosystem are fulfilled equitably. Integral to processes leading to social justice are community-based values, as long as these values serve individuals, families, communities, and the planet equitably. These values are, in many ways, compatible with and complimentary to Di Santo and Kenneally's (2014) rights-integrative approach to early learning.

\section{Community-based Values}

Community-based values include and are not limited to prevention and promotion (Albee, 1986; Nelson \& Caplan, 2014; Nelson, Prilleltensky, \& Hasford, 2009), empowerment (Rappaport, 1987; Zimmerman, 2000), diversity (Akkari, Loomis, \& Bauer, 2011; PaciniKetchabaw \& Berikoff, 2008; Trickett, 1996), and civic participation (Loomis \& Akkari, 2012). In pursuit of social justice, communitybased values support " the relationships of the individual to communities and society" and "seek to understand and to enhance quality of life for individuals, communities, and society" (Dalton, Elias, \& Wandersman, 2001, p. 5). Community-based values allow for conceptualizations of children, not only as individuals, but also as a relational community - a children's community-where children may feel "a sense of belonging, with a common perception of collective needs and priorities" and are "able to assume a collective responsibility for community decisions" (Jewkes \& Murcott, 1996, p. 556). Some of the values that are compatible with children's rights to protection and autonomy, nondiscrimination, and participation, include prevention and promotion, empowerment, diversity, and civic participation. These values must be understood, be embraced, and permeate all domains of social life to work toward social justice. To realize this goal, we build on the notion of conceptualizing social justice through early childhood curriculum frameworks by integrating community-based values at a community level, with children's rights as individuals. Work has been done to illuminate tensions and contradictions existing between specific individual versus collective rights and values, including problematizing differing values across cultures (e.g., Dahlberg et al., 2007). The focus of this paper, however, is to elucidate the complementarity and compatibility between 
specific child rights (protection and autonomy, nondiscrimination, and participation) and community-based values (prevention and promotion, empowerment, diversity, and civic participation), with an implicit recognition that values differ across and between cultures and social systems and across time and context.

\section{Conceptualizing Social Justice in Early Childhood Education Curricula}

Issues around social justice can be introduced using existing ECE curriculum frameworks as tools. A conceptualization of social justice is necessary to guide and support educators in building, modelling, teaching, and living social justice values by fulfilling children's rights both in and outside of the classroom. Integrating community-based values with the rights-integrative approach to early learning provides a holistic conceptualization of social justice.

Di Santo and Kenneally (2014) explained that a rights-integrative approach to early learning is "a teaching and learning practice that acknowledges the CRC [Convention on the Rights of the Child] explicitly and puts it into action, regardless of the philosophical framework that guides the program" (p. 396). They analyzed Ontario's ELECT document (Government of Ontario, 2007) through a rights-based lens and presented findings on ways that the document reflected (or failed to reflect) the four guiding principles of the UNCRC, both implicitly and explicitly. They described the need for educators to "move out of a child/educator-centred philosophy to one of creating a global community" (p. 396). Envisioning a global community of children — one that includes all children and only children - through a rights-based approach can be exemplified by a conceptualization of social justice that explicitly infuses communitybased values (see Figure 1).

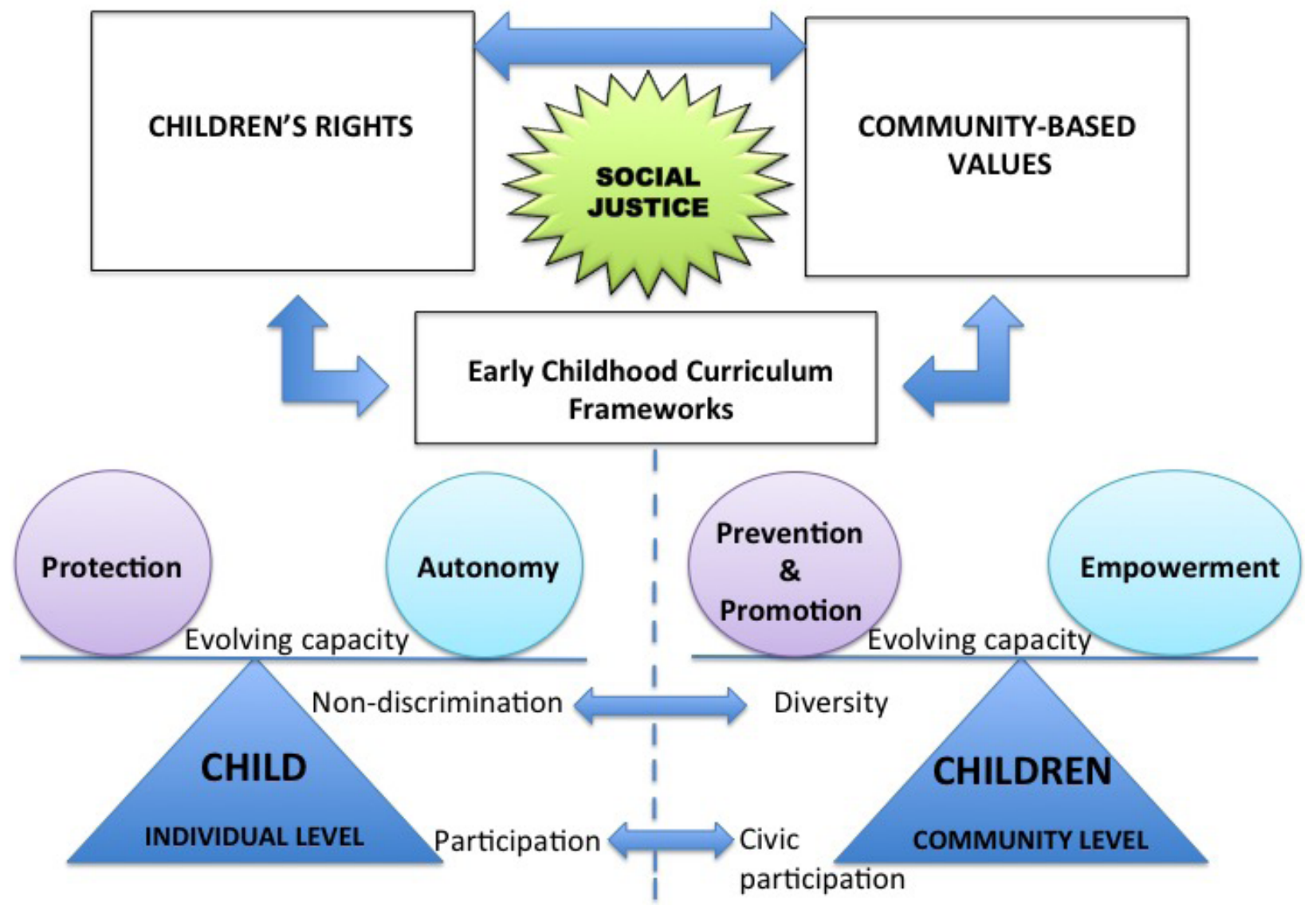

Figure 1. Conceptualization of social justice through early childhood curriculum frameworks. 
Figure 1 illustrates that integrating children's rights (top left square) with community-based values (top right square) in early childhood education is needed for social justice (individual and collective well-being) through early childhood curriculum frameworks (bottom central square). Left of dashed line, the individual child (blue triangle) is shown balancing (blue horizontal line) child's protection and autonomy rights, with the weight of each changing with evolving capacities of the child (adapted from Lansdown \& Wernham, 2012). Examples of a child's rights to nondiscrimination and participation are included. Right of the dashed line, children as a community (blue triangle) balance (blue horizontal line) community-based values of prevention and promotion, and empowerment, again with the weight of each changing with evolving capacities of children. Examples of diversity and civic participation are included. Generally, protection rights on an individual level are compatible with values of prevention and promotion (purple shading) on a collective level. Individual autonomy rights are compatible with empowerment (light blue shading) on a collective level. On an individual level, non-discrimination rights are compatible with the value of diversity on a collective level, and individual participation rights are compatible with civic participation on a collective level.

\section{Child's Rights to Protection and Autonomy with Their Evolving Capacity}

A child's rights to protection and autonomy are compatible, mutually reinforcing rights that must remain balanced, especially with the evolving capacities of the child changing over time (Lansdown \& Wernham, 2012). According to this particular framework, as the child matures, their capacity for making decisions based on issues affecting them increases, and they require less external protection from duty-bearers (e.g., parents, educators, government), whereas children who are less mature require higher levels of protection from dutybearers, hence limiting their autonomy. In all cases, however, the objective of those engaging with children should be to support the strengthening of the child's autonomy, which is in fact a means of protecting them. Ensuring that a child's rights are fulfilled through this balanced relationship between protection and autonomy may bring us closer to achieving justice for each individual child, but what about justice for children as a collective group or relational community?

Despite widespread social justice movements initiated and led by children (e.g., Malala Yousafzai, child activist and advocate for education for girls in Pakistan and globally [Kantor, 2014]) and Shannen Koostachin, youth advocate for First Nations children from Attawapiskat First Nation in Ontario, Canada [First Nations Child \& Family Caring Society of Canada, n.d.]), the capacities of children as a group (relational community) continue to be immensely underestimated. In other words, just as the capacity of an individual child can be underestimated, so can the collective capabilities of children as a whole. Children as a relational community remain marginalized from social, political, and economic processes that critically impact progress toward or away from social justice. As an example, we might ask why, in Canada, children can only vote or run for office when they turn 18 years old. How common is it for children to participate in curriculum development throughout their education, and if they participate, how meaningful and impactful is their involvement? Even the UNCRC itself, a document that affects every child directly, and which says that "State parties shall assure to the child who is capable of forming his or her own views the right to express those views freely in all matters affecting the child, the views of the child being given due weight in accordance with the age and maturity of the child" (United Nations, 1989, Article 12, p. 4), did not consult with children to develop the Convention. Why have our theories, practices, and policies in Canada not evolved congruent with our increased understandings of the capabilities of children as a group? One partial explanation is that adults have chosen to prioritize child protection rights over child autonomy rights. Conceptualizing children's rights on a community level in addition to the individual level will help us better develop and integrate theories, practices, pedagogies, policies, and, in this particular case, ECE curricula that balance the protection and autonomy rights of children as a community. For this conceptualization to be actualized, having a shared understanding of the compatibility between child rights and community-based values is necessary.

Compatibility of protection and autonomy rights with community-based values. Community-based values are compatible with $\mathrm{Di}$ Santo and Kenneally's (2014) rights-integrative approach to early learning and children's protection and autonomy rights. Integration of these values within the rights-integrative approach allows us to conceptualize children, not only as individuals with rights, but also as a relational community with rights, and therefore with a commitment to one another to ensure each others' well-being. On an individual level, protection rights are compatible with community-based values of prevention and promotion, and on an individual level, autonomy rights are compatible with the community-based value of empowerment.

Right to protection (individual child), and values of prevention and promotion (children as a collective). Rights-based approaches must go beyond conceptualizing protection rights "as simply a list of "protection rights" "and toward a "broader vision of protection as the positive promotion of optimal development and well-being" (Lansdown \& Wernham, 2012, p. 2). This broader vision can be described by community-based values of prevention of suffering (e.g., physical, emotional, social) and promotion of well-being. Positive health and well-being and high quality of living are the central objectives of prevention and promotion principles (Prilleltensky \& Nelson, 2000), and research shows that prevention programs lead to positive outcomes for children (e.g., see the Perry Preschool [Schweinhart, Barnes, 
\& Weikart, 1993] and Better Beginnings, Better Futures [Peters et al., 2010]). On an individual level, problem-solving skills may be taught with young children to promote competence, while on a meso level, school-based prevention programs may be implemented, and on a macro level, these principles are applied in ways to change public policy (Nelson \& Prilleltensky, 2010). Embracing communitybased values of prevention and promotion on multiple structural levels with communities of children and within early learning curricula can lead to fulfillment of the protection rights of each child. Furthermore, with the evolving capacity of children as a collective, just as protection rights must be balanced with autonomy rights for individual children, community-based values of prevention and promotion must be balanced with the community-based value of empowerment for children as a collective.

Right to autonomy (individual child) and value of empowerment (children as a collective). Autonomy involves having control over and being able to make choices and decisions for one's self. Working with young children on skills such as critical thinking and informed decision making is important to increasing personal autonomy (Lansdown \& Wernham, 2012). Just as autonomy rights must be realized for each individual child, they must also be fulfilled for children as a relational community, which is possible through community empowerment. Empowerment is "a process, a mechanism by which people, organizations, and communities gain mastery over their affairs" (Rappaport, 1987, p. 122). Fundamental to empowerment are relationships and power, whereby a common difficulty arises when attempting "power sharing," resulting in reproducing the status quo more implicitly. One way to counter reinforcing existing power structures is to embrace empowerment as a process to initiate social change (Angelique, 2008; Munger et al., 2016). To do so, in addition to working with young children on critical thinking and informed decision-making skills (that lead to autonomy), early learning curriculum frameworks can be used to guide educators to work with children on developing group-advocacy, capacity-building, and resource-mobilization skills (that lead to empowerment). For example, employing multimodal approaches to learning, such as through storytelling and storyacting (Paley, 1981), and pedagogical narrations (Atkinson, 2012; Pacini-Ketchabaw, Nxumalo, Kocher, Elliot, \& Sanchez, 2014), creates spaces where children can explore ways to overcome challenges together as a community, develop a sense of community, and better understand their individual roles within their broader community (Zepeda, 2014).

Compatibility of nondiscrimination and participation rights with community-based values. Community-based values of diversity and civic participation are compatible with each child's right to nondiscrimination and participation. Integration of these values within early learning frameworks enhances our conceptualization of a child's individual rights toward children's rights on a relational community level. On an individual level, nondiscrimination rights are compatible with the community-based value of diversity, and on an individual level, participation rights are compatible with the value of civic participation.

Right to nondiscrimination (individual child) and value of diversity (children as a collective). Nondiscrimination is one of the four guiding principles of the UNCRC (United Nations, 1989). Article 2 of the UNCRC states that every child has a right not to experience "discrimination of any kind, irrespective of the child's or his or her parent's or legal guardian's race, colour, sex, language, religion, political or other opinion, national, ethnic or social origin, property, disability, birth or other status" (United Nations, 1989, p. 2). While the right to nondiscrimination is essential to move toward justice for every child, we must broaden and deepen our understanding of what nondiscrimination means on a community level so that children as a community have their rights fulfilled. Nondiscrimination can be conceptualized as valuing diversity, which goes beyond accepting or including people/groups considered to differ from the "norm." Instead, actively seeking and integrating diversity into social contexts and celebrating, exploring, and engaging in diverse experiences as ongoing praxis can develop and promote diverse ideas, structures of leadership, and strategies to distribute and redistribute power within and between groups.

Within the ECEC classroom, Santora (2004) writes, "children need to see themselves, and people who represent the diversity of their families, their communities, and their world, in the environment in which they live, work, and play" (p. 4). Educators may enhance early learning curriculum frameworks to infuse their classroom communities with books, images, materials, activities, discussions, and celebrations that embody diverse family configurations (including, but not limited to, lesbian, gay, bisexual, transgendered, transsexual, two-spirited, and queer members), cultural and religious traditions, and socioeconomic statuses; nonstereotypical gender roles (such as male caregivers and female police officers), and varying abilities. Moreover, educators themselves can employ and encourage children to use diverse and inclusive language, such as "people first" language, whereby putting people before their circumstances (e.g., referring to "a person who is living with diabetes" as opposed to "a diabetic person" or a "family living in poverty" as opposed to a "poor family"); "gender neutral" language (e.g., referring to "firefighters" rather than "firemen"); and "nonheterosexist" language (e.g., referring to one's "partner" rather than one's "husband," "wife," "girlfriend," or "boyfriend"). Exploring philosophies around play through a "transcultural curriculum," for example, may help to facilitate these processes and create spaces to celebrate diversity within early learning centres and classrooms (Bjartveit \& Panayotidis, 2015). Immense diversity exists in individual and group characteristics (e.g., race, language, ideas, opinions), but recognizing the "contexts of diversity and the diversity of contexts ... [facilitates] an appreciation of how sociocultural diversity interacts with diversity in ecological contexts within which individuals live" (Trickett, 1996, p. 218). 
Right to participation (individual child) and value of civic participation (children as a collective). Article 31.1 of the UNCRC (United Nations, 1989) recognizes each child's right to "participate freely in cultural life and the arts" (p. 9), and Article 23.1 recognizes the rights of children with mental or physical disabilities to "enjoy a full and decent life, in conditions which ensure dignity, promote self-reliance and facilitate the child's active participation in the community" (p. 7). Participation rights are necessary to move toward justice for every child; however, conceptualizing participation on a community level as civic participation can contribute to fulfilling children's rights as a community. Citizen participation has been defined as "a process in which individuals take part in decision making in the institutions, programs, and environments that affect them" (Kloos et al., 2012, p. 354). Since the term citizenship (or citizen participation) has traditionally been used to exclude certain groups of people from participating fully in their communities, more inclusive concepts of citizenship (e.g., those that include all members of a community regardless of immigration status) are essential (Kloos et al., 2012). More inclusively, civic participation involves all community members, who make and execute important decisions, in ways that are fundamental to creating social change, rather than through tokenistic means. To embrace values of civic participation within early learning environments, early learning frameworks can guide educators in exploring, designing, and integrating strategies that encourage young children to make important decisions within their child care centres, their classrooms, and the activities they choose to participate in. Furthermore, educators can encourage dialogue and critical thinking around various ways that each child and educator might engage in democratic processes (e.g., turn taking, voting) and the benefits and consequences of civic participation for individual members of the community (each child and educator) and/or the community as a whole (child care centre or classroom).

\section{Conclusions}

Concerning ourselves with and conceptualizing the rights of individual children is critical, but we need to extend our perspectives to include children as a larger community. In addition to children's local communities, children are also members of a relational "children's community" that spans ability, gender, sex, culture, socioeconomic status, and other categorical boundaries that exist among them. Expanding conceptualizations around children and exploring ways in which rights-based, value-oriented curriculum can contribute to universal and high-quality early childhood education are essential in our pursuit of social justice.

The conceptual model presented in this paper can be used as a framework to develop, implement, and evaluate early learning frameworks across Canada and internationally. Furthermore, since all children's rights are of equal importance, additional child rights, including provisional rights - along with rights to autonomy, protection, nondiscrimination, and participation - can and should be explored and connected with community-based values of prevention and promotion, empowerment, diversity, civic participation, and other community-based values that have not been explored in this paper.

In order to work toward individual and collective well-being throughout Canada and across the globe, the rights of all living beings and the ecosystem must be fulfilled equitably. The lessons and practices necessary to achieve this goal must begin in early childhood, and can be achieved through two interconnected structural processes that must occur and be sustained simultaneously: provision of universal, accessible, high-quality early childhood education and care programs for every child, and provision of early childhood curriculum frameworks that integrate and infuse community-based values with a rights-integrative approach to early learning within those programs.

\section{References}

Akkari, A., Loomis, C., \& Bauer, S. (2011). From accommodating to using diversity by teachers in Switzerland. Journal of Multiculturalism in Education, 7(1), 1-11. Retrieved from: https://archive-ouverte.unige.ch/unige:20229/ATTACHMENT01

Albee, G. W. (1986). Toward a just society: Lessons from observations on the primary prevention of psychopathology. American Psychologist, 41, 891-898. doi: 10.1037/0003066X.41.8.891

Angelique, H. L. (2008). On power, psychopolitical validity, and play. Journal of Community Psychology, 36(2), 246-253. doi: 10.1002/ jcop. 20235

Atkinson, K. (2012). Pedagogical narration: What's it all about? An introduction to the process of using pedagogical narration in practice. The Early Childhood Educator, 27, 3-7. 
Bjartveit, C., \& Panayotidis, L. (2015). Running with Hermes: Imagining and traversing a transcultural curriculum path in the postsecondary early childhood education classroom. Canadian Children, 40(3), 4-15.

Cannella, G. S. (1997). Deconstructing early childhood education: Social justice and revolution (Vol. 2). New York, NY: Peter Lang.

Dahlberg, G., Moss, P., Pence, A. R. (2007). Beyond quality in early childhood education and care: Languages of evaluation ( $2^{\text {nd }}$ ed.). New York, NY: Routledge.

Dalton, J., Elias, M., \& Wandersman, A. (2001). Community psychology: Linking individuals and communities. Belmont, CA: Wadsworth/ Thomson Learning.

Di Santo, A., \& Kenneally, N. (2014). A call for a shift in thinking: Viewing children as rights-holders in early childhood curriculum frameworks. Childhood Education, 90(6), 395-406. doi: 10.1080/00094056.2014.982969

Evans, S. D., Rosen, A., \& Nelson, G. (2014). Community psychology and social justice. In C. V. Johnson, H. L. Friedman, J. Diaz, Z. Franco, \& B. K. Nastasi (Eds.), Praeger handbook of social justice and psychology (pp. 143-163). Denver, CO: Praeger.

First Nations Child \& Family Caring Society of Canada. (n.d.). Shannen's dream: About Shannen Koostachin. Retrieved from: https:// fncaringsociety.com/about-shannen-koostachin

Friendly, M., \& Prentice, S. (2009). About Canada: Childcare. Halifax, NS: Fernwood.

Gallahue, D., \& Ozmun, J. (2011). Understanding motor development: Infants, children, adolescents, adults (7th ed.). New York, NY: McGraw-Hill.

Government of British Columbia. (2008). British Columbia early learning framework. Victoria, BC: Ministry of Health and Ministry of Children and Family Development.

Government of Ontario. (2007). Early learning for every child today. Toronto, ON: Best Start Panel on an Early Learning Program.

Jewkes, R., \& Murcott, A. (1996). Meanings of community. Social Science \& Medicine, 43(4), 555-563. doi: 10.1016/02779536(95)00439-4

Kantor, J. (2014, October 10). Malala Yousafzai, youngest Nobel Peace Prize winner, adds to her achievements and expectations. The New York Times. Retrieved from: http://www.nytimes.com/2014/10/11/world/asia/malala-yousafzai-youngest-nobel-peaceprize-winner-adds-to-her-achievements-and-expectations.html?_r=0

Kloos, B., Hill, J., Thomas, E., Wandersman, A., Elias, M. J., \& Dalton, J. H. (2012). Community psychology: Linking individuals and communities ( $3^{\text {rd }}$ ed.). Belmont, CA: Wadsworth.

Kruger, M. (2004). The concept and practice of justice in an intentional community: The East Wind experience. Contemporary Justice Review: Issues in Criminal, Social, and Restorative Justice, 7, 355-374. doi: 10.1080/1028258042000305857

Langford, R. (2012). Innovations in provincial early learning curriculum frameworks. In N. Howe \& L. Prochner (Eds.), Recent perspectives on early childhood education and care in Canada (pp. 206-228). Toronto, ON: University of Toronto Press.

Lansdown, G., \& Wernham, M. (2012). No. 3: Understanding young people's rights to decide: Are protection and autonomy opposing concepts? London, England: International Planned Parenthood Federation.

Loomis, C., \& Akkari, A. (2012). From the will to the field: Parent participation in early childhood education in Madagascar. Africa Development, 37(3), 87-99.

Munger, F., MacLeod, T., \& Loomis, C. (2016). Social change: Towards an informed and critical understanding of social justice and the capabilities approach in community psychology. American Journal of Community Psychology, 57(1-2), 171-180. doi: 10.1002/ 
ajcp. 12034

Nelson, G., \& Caplan, R. (2014). The prevention of child physical abuse and neglect: An update. Journal of Applied Research on Children: Informing Policy for Children at Risk, 5, Article 3.

Nelson, G., \& Prilleltensky, I. (Eds.). (2010). Community psychology: In pursuit of liberation and well-being (2 ${ }^{\text {nd }}$ ed.). New York, NY: Palgrave.

Nelson, G., Prilleltensky, I., \& Hasford, J. (2009). Prevention and mental health promotion in the community. In D. Dozois \& P. Firestone (Eds.), Abnormal psychology: Perspectives (4 ${ }^{\text {th }}$ ed., pp. 440-457). Scarborough, ON: Prentice-Hall.

Pacini-Ketchabaw, V., \& Berikoff, A. (2008). The politics of difference and diversity: From young children's violence to creative power expressions. Contemporary Issues in Early Childhood, 9(3), 256-264. doi: 10.2304/ciec.2008.9.3.256

Pacini-Ketchabaw, V., Nxumalo, F., Kocher, L., Elliot, E., \& Sanchez, A. (2014). Journeys: Reconceptualizing early childhood practices through pedagogical narration. Toronto, ON: University of Toronto Press.

Paley, V. (1981). Wally's stories: Conversations in the kindergarten. Cambridge, MA: Harvard University Press.

Pelo, A. (2008). Rethinking early childhood education. Milwaukee, WI: Rethinking Schools.

Penn, H. (2008). Understanding early childhood: Issues and controversies. Maidenhead, England: McGraw-Hill/Open University Press.

Peters, R. DeV., Bradshaw, A. J., Petrunka, K., Nelson, G., Herry, Y., Craig., W. M., et al. (2010). The Better Beginnings, Better Futures project: Parent, family, and community outcomes at grades 6 and 9 of a universal, comprehensive, community-based prevention approach for primary school children and their families. Monographs of the Society for Research in Child Development, 75(3), 1-246. doi: 10.1111/j.1540-5834.2010.00577.x

Prilleltensky, I., \& Nelson, G. (2000). Promoting child and family wellness: Priorities for psychological and social interventions. Journal of Community \& Applied Social Psychology, 10, 85-105. doi: 10.1002/(SICI)1099-1298(200003/04)10:2<85::AIDCASP538>3.0.CO;2-M

Rappaport, J. (1987). Terms of empowerment/exemplars of prevention: Toward a theory for community psychology. American Journal of Community Psychology, 13(2), 121-148. doi: 10.1007/BF00919275

Riemer, M., \& Van Voorhees, C. W. (2014). Sustainability and social justice. In C. Johnson, H. Friedman, J. Diaz, B. Nastasi, \& Z. Franco (Eds.), Praeger handbook of social justice and psychology (pp. 49-66). Westport, CT: Praeger.

Santora, L. (2004). How can you create a learning environment that respects diversity? Retrieved from: http://www.adl.org/assets/pdf/ education-outreach/How-Can-You-Create-a-Learning-Environment-That-Respects-Diversity.pdf

Schoorman, D. (2011). Reconceptualizing teacher education as a social justice undertaking: Underscoring the urgency for critical multiculturalism in early childhood education [Special issue]. Childhood Education, 87(5), 341-344. doi: $10.1080 / 00094056.2011 .10523210$

Schweinhart, L., Barnes, H., \& Weikart, D. (1993). Significant benefits: The High/Scope Perry Preschool study through age 27. Ypsilanti, MI: High/Scope Press.

Sloan, T. (2010). Globalization, poverty, and social justice. In G. Nelson \& I. Prilleltensky (Eds.), Community psychology: In pursuit of liberation and well-being ( $2^{\text {nd }}$ ed.; pp. 309-329). New York, NY: Palgrave Macmillan.

Trickett, E. J. (1996). A future for community psychology: The contexts of diversity and the diversity of contexts. American Journal of Community Psychology, 24(2), 209-234. doi: 10.1007/BF02510399 
United Nations. (1989). Convention on the rights of the child. New York, NY: Author.

Victorian Curriculum and Assessment Authority. (2008). Analysis of curriculum/learning frameworks for the early years (birth to age 8). Retrieved from: http://www.vcaa.vic.edu.au/Documents/earlyyears/analysiscurriclearnfwlitreview.pdf

Zepeda, J. (2014). Stories in the classroom: Building community using storytelling and storyacting. Canadian Children, 39(2), 21-26.

Zimmerman, M. A. (2000). Empowerment theory. In Handbook of community psychology (pp. 43-63). New York, NY: Springer US. 